\title{
NATURAL RADIOACTIVITY IN DRINKING WATER FROM GALATI AND VRANCEA AREAS, ROMANIA*
}

\author{
Violeta Pintilie $^{1 * *}$, Lucian-Puiu Georgescu$^{2}$, Luminita Moraru$^{2}$, \\ Antoaneta Ene ${ }^{2}$, Catalina Iticescu ${ }^{2}$
}

\author{
${ }^{1}$ Department of Public Health Galati, Ionizing Radiation Laboratory, Galati, Romania \\ ${ }^{2}$ Dunarea de Jos University of Galati, Faculty of Sciences and Environment, Department of Chemistry, \\ Physics and Environment, Galati, Romania
}

\begin{abstract}
Pollution and contamination of drinking water grow rapidly due to industrial growth and urbanization. They potentially cause severe problems to health, so the water quality management addresses both national and international action to assess and prevent the associated hazard. The quality of drinking water must be strictly controlled. The aim of the study was to determine the concentration of ${ }^{210} \mathrm{Po},{ }^{210} \mathrm{~Pb},{ }^{226} \mathrm{Ra}$ in drinking water. The occurrence of ${ }^{210} \mathrm{Po}$ and ${ }^{210} \mathrm{~Pb}$ has been determined by spontaneous deposition onto a nickel disc and the gross alpha activity has been measured. ${ }^{226}$ Ra has been measured after 30 days of storage in order to be sure that ${ }^{222} \mathrm{Rn}$ in water samples reached secular equilibrium. Water samples were collected from a total of 17 sites, which serve 556,125 persons, in Galati and Vrancea areas of the East part of Romania. Samples were collected during March and April of 2015. The monitoring of drinking water samples indicated the presence of ${ }^{210} \mathrm{Po},{ }^{210} \mathrm{~Pb},{ }^{226} \mathrm{Ra}$ at a concentration ranging from 1.9 to $12.5 \mathrm{mBq} \mathrm{L} L^{-1}, 3.2$ and $15.9 \mathrm{mBq} \mathrm{L^{-1 }}$, 8.0 and $30.0 \mathrm{mBq} \mathrm{L}^{-1}$, respectively. These values were compared with the maximum permitted level, according to national legislation. The average annual committed effective dose from the intake of water ranged between $4.15 \times 10^{-3}$ and $18.80 \times 10^{-3} \mathrm{mSv}^{-1}$, for adults, which is lower than the recommended reference value of $0.1 \mathrm{mSv}$ in water for human consumption according to the current EU legislation.
\end{abstract}

Key words: Water, polonium, radium, lead, equivalent effective dose, Galati, Vrancea

\section{INTRODUCTION}

Drinking water is the most important water for humankind. The consumed water participates in all cellular processes, but simultaneously it is a way for the ingestion of radionuclides and can pose a number of health hazards. UNSCEAR estimates that the natural sources have a contribution of $2.4 \mathrm{mSv}^{-1}$ to the effective dose, a value which includes the contribution of $0.3 \mathrm{mSv} \mathrm{y}^{-1}$ due to the usage of aliments and water [1].

The quantification of the radiological quality of drinking water is made through the calculation of the effective dose equivalent due to its ingestion, after determining the concentration of radionuclides occurring in water.

The World Health Organization (WHO) and the European Directive 2013/51 recommended a value of $0.1 \mathrm{mSv}$ for the effective dose equivalent for one person per year, as a safe level [2], [3]. The natural radionuclides from drinking water come from three naturally radioactive series: thorium series, actinium series and uranium series. In the case of natural radionuclides of uranium and thorium series, the effective dose conversion factor by ingestion for adults grows in the following order:
Polonium is the most radiotoxic alpha emitter, due to the relatively high energy $(5.3 \mathrm{MeV})$, and it is concentrated in soft tissues, such as muscles and liver, or produces sclerotic changes in blood vessels [4]. Lead tends to accumulate in bone but is also distributed to the brain, liver and kidney. ${ }^{210} \mathrm{Po}$ and ${ }^{210} \mathrm{~Pb}$ might be present inside the body in the absence of direct intake from decay of ${ }^{226} \mathrm{Ra}$ [1]. The radium's metabolism is similar to the metabolism of calcium and a considerable amount is stored in the bones [5].

The guidance levels for ${ }^{210} \mathrm{Po}$ and ${ }^{210} \mathrm{~Pb}$ are of $0.1 \mathrm{~Bq}$ $\mathrm{L}^{-1}$ and for ${ }^{226} \mathrm{Ra}$ is $1 \mathrm{~Bq} \mathrm{~L} \mathrm{~L}^{-1}$, according to the "Guidelines for drinking water quality-third edition"WHO 2008 [6]. The derived concentrations for radioactivity in water intended for human consumption for ${ }^{226} \mathrm{Ra}$, ${ }^{210} \mathrm{Po}$, and ${ }^{210} \mathrm{~Pb}$ are $0.5 \mathrm{~Bq} \mathrm{~L}^{-1}$, $0.1 \mathrm{~Bq} \mathrm{~L}^{-1}$, and 0.2 $\mathrm{Bq} \mathrm{L}^{-1}$, respectively [3].

The main goal of this study was to determine the gross alpha activity, gross beta activity and specific activities of ${ }^{210} \mathrm{Po},{ }^{210} \mathrm{~Pb}$ and ${ }^{226} \mathrm{Ra}$ in drinking water from Galati and Vrancea areas of the Eastern part of Romania and to assess the effective dose equivalent due to the ingestion of radionuclides from drinking water.

$$
{ }^{238} \mathrm{U}<235 \mathrm{U}<234 \mathrm{U}<{ }^{224} \mathrm{Ra}<{ }^{226} \mathrm{Ra}<{ }^{210} \mathrm{~Pb}<{ }^{228} \mathrm{Ra}<{ }^{210} \mathrm{Po}
$$

\footnotetext{
*The paper was presented at the Fourth International Conference on Radiation and Applications in Various Fields of Research (RAD 2016), Niš, Serbia, 2016.
}

*violetapintilie18@gmail.com 


\section{EXPERIMENTAL}

\subsection{Studied area and sampling}

The analysis of drinking water was carried out in Galati and Vrancea counties, two areas located in the Eastern part of Romania, representing $4.3 \%$ of the surface of the country (Fig.1). The Galati County is situated between $45^{\circ} 25^{\prime}$ and $46^{\circ} 10^{\prime}$ North latitude and $27^{\circ} 20^{\prime}$ and $28^{\circ} 10^{\prime}$ East longitude [7] and Vrancea County between $45^{\circ} 23^{\prime}$ and $46^{\circ} 11^{\prime}$ North latitude and $26^{\circ} 23^{\prime}$ and $27^{\circ} 32^{\prime}$ East longitude [8].

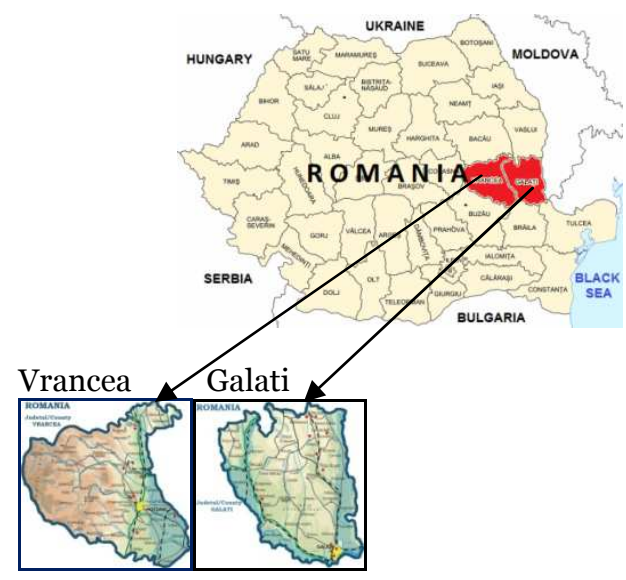

Figure 1. The sampling area in Galati and Vrancea counties, Romania (2015)

Galati County includes four urban localities (two municipalities- Galati and Tecuci, and two cities- Tg. Bujor and Beresti) and 61 communes, totaling 181 villages. The urban water supplying the Galati municipality is provided by two waterworks which use two water sources (labeled as DW1 and DW2). For the Tecuci municipality, the two other cities and six communes, the drinking water samples were collected from sources labeled DW3 -DW11.

Vrancea County includes five urban localities (two municipalities - Focsani and Adjud, and three cities Marasesti, Odobesti and Panciu) and 68 communes, totaling 331 villages. From all five urban localities and one commune of the Vrancea County, drinking water samples labeled DW12-DW17 were collected and analyzed.

From all the 17 samples, one sample has surface water (the Danube River) as a source, three samples have a captured spring as a source, and the others have drilled wells as a source.

\subsection{Measurement of the gross alpha/beta activity}

The gross alpha activity and gross beta activity measurements represent the general screening of the radiological quality of drinking water; in the case that the measured values of radioactivity do not exceed the screening value adopted by World Health Organization [2], the annual effective doses are bellow the recommended reference level of $0.1 \mathrm{mSv} \mathrm{y}^{-1}$, and no further radiological investigation for specific radionuclides is required [3].
To obtain a sufficient amount of residues for radiometric measurements, the amount of evaporated water and the total dissolved solid substance $\left(\mathrm{mg} \mathrm{L}^{-1}\right)$ was determined.

The alpha/beta activity was determined in accordance with ISO 9696 and ISO 9697, respectively [9], [10]. The sample stabilized by acidification is evaporated almost to dryness, converted to the sulphate form and ashed at $350^{\circ} \mathrm{C}$. A part of the obtained sample residue is transferred to a stainless steel planchet. The activity of the stainless steel planchet with residue was measured. Gross alpha/beta activity of the sample was measured using lowbackground MPC-2000-DP system (Protean Instruments Corporation) [11], calibrated at the National R\&D Institute for Physics and Nuclear Engineering IFIN-HH, Bucharest. The counter MPC2000-DP is equipped with a dual phosphor scintillator type detector. The samples were simultaneously measured in alpha and beta mode. The weight of the sample transferred to the stainless planchet was approximately $90 \mathrm{mg}$. This value was established according to the self-absorption curve. The calibration of MPC-2000-DP system was made by using two standard sources: ${ }^{241} \mathrm{Am}$ (serial no: 2830, LMRI France) and ${ }^{\circ} \mathrm{Sr} / \mathrm{Y}$ (serial no:9891, LMRI France). The measurements were performed during a period of 30 minutes, ten times per sample.

The gross alpha or is beta activity calculated using equation (1):

$$
A_{\alpha / \beta}=\frac{\left(R_{\alpha / \beta}-R_{0}\right) \times T D S}{m \times \varepsilon} \quad \mathrm{Bq} \mathrm{L}^{-1}
$$

where $A_{\alpha / \beta}$ is the gross alpha/beta activity of the drinking water sample, $R_{\alpha / \beta}$ is the rate of alpha/beta measurement for the sample (counts $s^{-1}$ ), $R_{0}$ is the rate of alpha/beta measurement for background (counts $\mathrm{s}^{-}$ 1), TDS is the concentration of the total dissolved solids of the sample $\left(\mathrm{g} \mathrm{L}^{-1}\right), \mathrm{m}$ is the weight of residue transferred to a stainless steel planchet for measurements (g) and $\varepsilon$ is the efficiency of the detector.

\subsection{Determination of ${ }^{210} \mathrm{Po}$ and ${ }^{210} \mathrm{~Pb}$ concentration}

The concentration of ${ }^{210} \mathrm{Po}$ and ${ }^{210} \mathrm{~Pb}$ was determined in accordance with STAS 1244-86 [12], [13].

A quantity of $4 \mathrm{~L}$ of each water sample was acidified up to $\mathrm{pH}=2$. Then, the sample was mineralized as follows: evaporation of the sample to near dryness; addition of $5 \mathrm{~mL} \mathrm{HNO}_{3}$ (density of $1.40 \mathrm{~g} \mathrm{~L}^{-1}$ ) and $5 \mathrm{~mL}$ $\mathrm{H} 2 \mathrm{O} 2$ (30\%), followed by evaporation - this step was repeated 4-5 times until white residue was obtained (up to getting a white residue). The white residue was dissolved in $15 \mathrm{~mL} \mathrm{HCl}$ (density of $1.19 \mathrm{~g} \mathrm{~L}^{-1}$ ) and then was evaporated to near dryness- this step was repeated twice. In this way, a white mineralized residue developed, which was transferred in a beaker with $15 \mathrm{~mL} \mathrm{HCl}$ (density of $1.19 \mathrm{~g} / \mathrm{L}$ ) and $15 \mathrm{~mL}$ of distilled water. The solution was diluted to $100 \mathrm{~mL}$ with distilled water. Then, $\mathrm{NaOH}(30 \%)$ was used to neutralize the sample in the presence of the phenolphthalein. The neutral solution was acidified with $\mathrm{HCl}$ (density of $1.19 \mathrm{~g} \mathrm{~L}^{-1}$ ) up to $\mathrm{pH}$ of 1.5 and 200 
mg of ascorbic acid was added to prevent co-plating of interfering ions. In the end, ${ }^{210} \mathrm{Po}$ in the solution was spontaneously plated for four hours on a nickel disc. Also, the system was heated at $90{ }^{\circ} \mathrm{C}$. Gross alpha activity of the nickel disc was measured using MPC2000-DP system, during a period of 400 minutes. The specific activity of ${ }^{210} \mathrm{Po}$ is calculated as:

$$
A_{210 P_{o}}=\frac{\left(R_{\text {sample }}-R_{0}\right)}{V_{\text {sample }} \times \mathcal{E} \times \eta} \quad \mathrm{Bq} \mathrm{L}^{-1}
$$

where $\mathrm{A}_{210}$ Po is the activity concentration of the sample (Bq $\left.\mathrm{L}^{-1}\right), \mathrm{R}_{\text {sample }}$ is the rate of measurement for the sample (counts $\mathrm{s}^{-1}$ ), $\mathrm{R}_{0}$ is the rate of measurement for background (counts $\mathrm{s}^{-1}$ ), $\mathrm{V}_{\text {sample }}$ is the volume of the sample (L) and $\eta$ is the chemical recovery of radiochemical separation.

The rest of the solution was stored for three months and then the procedure of spontaneous deposition on the nickel disc was repeated. The nickel disc is gross alpha measured. ${ }^{210} \mathrm{~Pb}$ activity is determined through its daughter ${ }^{210} \mathrm{Po}$.

The new activity concentration of ${ }^{210} \mathrm{~Pb}$ is calculated using the corrected formula:

$$
A_{210 \mathrm{~Pb}}=\frac{\left(R_{\text {sample }}-R_{0}\right)}{V_{\text {sample }} \times \mathcal{E} \times \eta \times 0.37} \quad \mathrm{~Bq} \mathrm{~L}^{-1}
$$

where 0.37 is a correction factor which indicates the value of the secular equilibrium stage of ${ }^{210} \mathrm{Po}$ and ${ }^{210} \mathrm{~Pb}$ after three months.

Since the method used does not allow simultaneous determinations of recovery yield and the concentration of $\mathrm{Po}-210$ or $\mathrm{Pb}-210$, in this paper a recovery yield at the amount of $100 \%$ was considered.

Therefore the concentrations determined for ${ }^{210} \mathrm{Po}$ and ${ }^{210} \mathrm{~Pb}$ may be higher.

\subsection{Determination of ${ }^{226} \mathrm{Ra}$ concentration}

Ra-226 measurement method indicated in the instructions for use of the instrument SARAD-RTM were used [14].

The water samples were stored 30 days in a sealed system before the determination of the activity of ${ }^{226} \mathrm{Ra}$ (Fig. 2). At the end of this period, enough ${ }^{222} \mathrm{Rn}$ was built up from ${ }^{226}$ Ra water samples.

After this period, the bubbling flask was connected to the module SARAD RTM 1688-2, without being opened, using Mohr's clamps (Fig. 3). After the connection of the bubbling flask to the measurement system, the Mohr's clamp was opened in such a way that the water did not come into contact with the air outside.

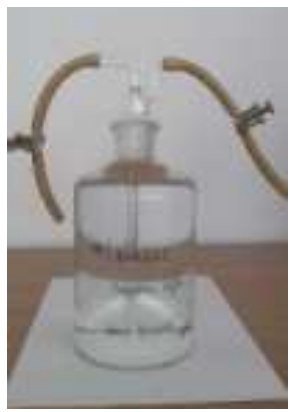

Figure 2. The sample sealed and stored for 30 days
The measurements were performed for 30 minutes and were repeated four times for each sample. Before each sample's measurement, the module, all connection tubes and the optional protection flask had to be flushed with fresh air for at least 15 minutes.

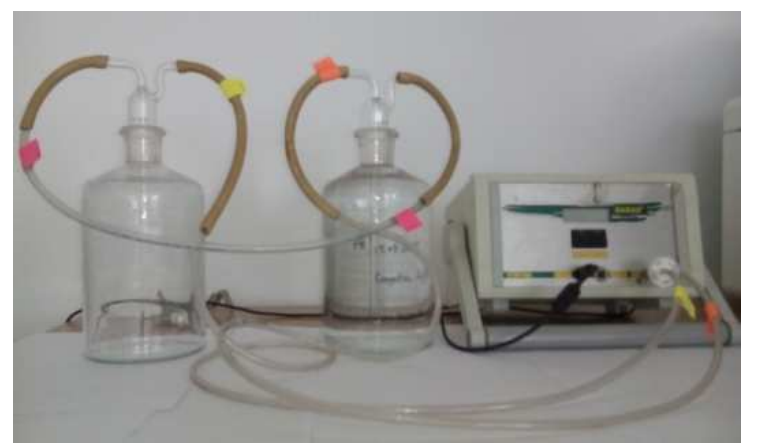

Figure 3. SARAD RTM-1688-2 measuring system for ${ }^{226} \mathrm{Ra}$ in water

The acquired measurement data are downloaded to the serial interface. The software calculates the activity concentration of ${ }^{226} \mathrm{Ra}\left(\mathrm{Bq} \mathrm{L}^{-1}\right)$ using the equation [14]:

$$
A_{226 R a}=\frac{1}{V_{\text {sample }}} \times C_{\text {air }} \times\left[k \times V_{\text {sample }}+V_{\text {air }}\right] \quad \text { Bq L } \mathrm{L}^{-1}
$$

here, $\mathrm{A}_{226 \mathrm{Ra}}$ - the activity concentration of ${ }^{226} \mathrm{Ra}$ (Bq L-1), $\mathrm{V}_{\text {sample }}$ - the volume of the sample (L), $\mathrm{C}_{\text {air }}-$ the value indicated by the measuring system (Bq L-1), $\mathrm{V}_{\text {air }}$ - the volume of the air from the measuring system (L), $\mathrm{k}$ - the temperature correction factor.

\section{RESULTS AND DISCUSSION}

\subsection{Activity concentration}

The values of the activity concentrations for gross alpha, gross beta, ${ }^{210} \mathrm{Po},{ }^{210} \mathrm{~Pb}$ and ${ }^{226} \mathrm{Ra}$, together with total dissolved substances (TDS) and total population in each investigated site are presented in Table 1 . No exceeding of the maximum permitted limits was registered for gross alpha activity (100 $\left.\mathrm{mBq} \mathrm{L}^{-1}\right)$, gross beta activity (1000 $\left.\mathrm{mBq} \mathrm{L}^{-1}\right)$, and activity concentration of ${ }^{210} \mathrm{Po}\left(136 \mathrm{mBq} \mathrm{L}{ }^{-1}\right),{ }^{210} \mathrm{~Pb}\left(25 \mathrm{mBq} \mathrm{L} \mathrm{L}^{-1}\right)$, and ${ }^{226} \mathrm{Ra}$ $\left(88 \mathrm{mBq} \mathrm{L}^{-1}\right)$ stipulated in the national legislation [15 ].

For the all samples, the ratio between gross alpha activity and gross beta activity is lower than 1 . In the case of three samples, gross alpha activity shows values lower than $6.0 \mathrm{mBq} \mathrm{L} \mathrm{L}^{-1}$, which is the minimum detectable activity. The highest value of gross alpha activity was found in the sample DW16, which belongs to Marasesti city, Vrancea. The highest gross beta activity was found in Gugesti, Vrancea (the sample DW17). Also, at this site, the highest value for activity concentration of $210 \mathrm{~Pb}$ was found. The highest activity concentration of ${ }^{226} \mathrm{Ra}$ and ${ }^{210} \mathrm{Po}$ was found in Galati (DW1 and DW7, respectively). 
V. Pintilie et al., Natural Radioactivity in Drinking Water..., Rad. Applic., 2016, 1, 3, 165-170 Table 1. Gross alpha, gross beta, and radionuclide activity concentration (in $\mathrm{mBq} \mathrm{L}^{-1}$ ) in drinking water samples from Galati and Vrancea areas, Romania, in 2015

\begin{tabular}{|c|c|c|c|c|c|c|c|c|}
\hline \begin{tabular}{|l}
$\begin{array}{l}\text { Sample } \\
\text { code }\end{array}$ \\
\end{tabular} & Source & Persons & $\begin{array}{c}\mathrm{TDS} \\
\left(\mathrm{mg} \mathrm{L}^{-1}\right)\end{array}$ & $\begin{array}{c}\mathrm{A}_{\alpha} \\
\left(\mathrm{mBq} \mathrm{L}^{-1}\right)\end{array}$ & $\begin{array}{c}\mathrm{A}_{\beta} \\
\left(\mathrm{mBq} \mathrm{L}^{-1}\right)\end{array}$ & $\begin{array}{c}\mathrm{A}_{210 \mathrm{Po}} \\
\left(\mathrm{mBq} \mathrm{L}^{-1}\right)\end{array}$ & $\begin{array}{c}\mathrm{A}_{210 \mathrm{~Pb}} \\
\left(\mathrm{mBq} \mathrm{L}^{-1}\right)\end{array}$ & $\begin{array}{c}\mathrm{A}_{226 \mathrm{Ra}} \\
\left(\mathrm{mBq} \mathrm{L}^{-1}\right)\end{array}$ \\
\hline DW1 & $\begin{array}{l}\text { surface } \\
\text { water } \\
\text { (Danube } \\
\text { River) }\end{array}$ & 260000 & 564 & $6.0 \pm 2.4$ & $412.3 \pm 123 \cdot 7$ & $2.0 \pm 0.4$ & $3.3 \pm 0.7$ & $30.0 \pm 9.0$ \\
\hline DW2 & drilled wells & 104000 & 732 & $8.4 \pm 3.4$ & $416.8 \pm 125.0$ & $1.9 \pm 0.4$ & $3.2 \pm 0.7$ & $23.0 \pm 6.9$ \\
\hline DW3 & drilled wells & 28000 & 504 & $8.7 \pm 3.5$ & $221.6 \pm 66.5$ & $2.0 \pm 0.4$ & $5.3 \pm 1.2$ & $13.0 \pm 3.9$ \\
\hline DW4 & $\begin{array}{l}\text { captured } \\
\text { spring }\end{array}$ & 1905 & 756 & $39.0 \pm 11.7$ & $219.9 \pm 66.0$ & $12.0 \pm 2.6$ & $8.4 \pm 1.7$ & $27.0 \pm 8.1$ \\
\hline DW5 & drilled wells & 4425 & 776 & $13 \cdot 3 \pm 5 \cdot 3$ & $389.9 \pm 117.0$ & $12.2 \pm 2.7$ & $3.3 \pm 0.8$ & $20.0 \pm 6.0$ \\
\hline DW6 & $\begin{array}{l}\text { captured } \\
\text { spring }\end{array}$ & 669 & 1016 & $6.0 \pm 2.4$ & $628.4 \pm 188.5$ & $2.0 \pm 0.4$ & $11.7 \pm 2.7$ & $18.0 \pm 5.4$ \\
\hline DW7 & $\begin{array}{l}\text { captured } \\
\text { spring }\end{array}$ & 345 & 736 & $16.8 \pm 6.7$ & $484.8 \pm 145.4$ & $12.5 \pm 2.7$ & $3.8 \pm 0.9$ & $27.0 \pm 8.1$ \\
\hline DW8 & drilled wells & 750 & 864 & $6.0 \pm 2.4$ & $564.0 \pm 169.2$ & $2.4 \pm 0.5$ & $7.5 \pm 1.5$ & $20.0 \pm 6.0$ \\
\hline DW9 & drilled wells & 600 & 968 & $27.7 \pm 11.1$ & $677.3 \pm 203.2$ & $2.5 \pm 0.6$ & $5.3 \pm 1.1$ & $27.0 \pm 8.1$ \\
\hline DW10 & drilled wells & 771 & 684 & $27.7 \pm 11.1$ & $313.4 \pm 94.0$ & $2.0 \pm 0.4$ & $3.8 \pm 0.8$ & $23.0 \pm 6.9$ \\
\hline DW11 & drilled wells & 825 & 968 & $19.6 \pm 7.8$ & $226.6 \pm 68.0$ & $7.8 \pm 1.7$ & $7.7 \pm 1.5$ & $8.0 \pm 2.4$ \\
\hline DW12 & drilled wells & 18432 & 744 & $21.1 \pm 8.4$ & $91.6 \pm 27.5$ & $2.8 \pm 0.6$ & $3.3 \pm 0.7$ & $8.0 \pm 2.4$ \\
\hline DW13 & drilled wells & 98646 & 1032 & $56.8 \pm 22.7$ & $329.7 \pm 98.9$ & $2.0 \pm 0.4$ & $6.3 \pm 1.4$ & $8.0 \pm 2.4$ \\
\hline DW14 & drilled wells & 8566 & 668 & $36.8 \pm 14.7$ & $122.9 \pm 36.9$ & $1.9 \pm 0.4$ & $3.4 \pm 0.7$ & $15.0 \pm 4.5$ \\
\hline DW15 & drilled wells & 8735 & 592 & $9.8 \pm 3.9$ & $615.4 \pm 184.6$ & $2.0 \pm 0.4$ & $4.4 \pm 1.0$ & $24.0 \pm 7.2$ \\
\hline DW16 & drilled wells & 12667 & 692 & $57.1 \pm 22.9$ & $324.1 \pm 97.2$ & $2.0 \pm 0.4$ & $3.2 \pm 0.0$ & $27.0 \pm 8.1$ \\
\hline DW17 & drilled wells & 6789 & 888 & $20.0 \pm 8.0$ & $901.2 \pm 270.4$ & $4.5 \pm 1.0$ & $15.9 \pm 3.7$ & $14.0 \pm 4.2$ \\
\hline mean & & & 775.52 & $22.4 \pm 8.7$ & $408.2 \pm 122.5$ & $4.4 \pm 1.0$ & $2.9 \pm 1.2$ & $19.5 \pm 5.8$ \\
\hline range & All sources* & $556125^{* *}$ & $\begin{array}{l}504- \\
1032 \\
\end{array}$ & $<6-57.1$ & 91.6-901.2 & $1.9-12.5$ & $3.21-15.9$ & $8-30$ \\
\hline
\end{tabular}

${ }^{*}$ surface water, captured spring, drilled wells;

**the sum of water users (Galati and Vrancea, Romania).

From Table 1 it can be seen that the average value of TDS concentration for Galati samples (DW1 - DW11) is $760 \mathrm{mg} \mathrm{L}^{-1}$ and is comparable with the average value of $797 \mathrm{mg} \mathrm{L}^{-1}$ obtained for Vrancea samples (DW12 DW17). The observed gross alpha activity found in the first data set (expressed in average \pm standard deviation) is $16.3 \pm 11.1 \mathrm{mBq} \mathrm{L}{ }^{-1}$, while for the second data set is $33.6 \pm 20.0 \mathrm{mg} \mathrm{L}^{-1}$. The average value for gross beta activity is $432.8 \pm 129.8 \mathrm{mBq} \mathrm{L}-1$ for the first data set and $373.5^{ \pm 111.9} \mathrm{mBq} \mathrm{L^{-1 }}$ for the second data set. The activity concentrations of ${ }^{210} \mathrm{Po}$ and ${ }^{226} \mathrm{Ra}$ are 1.5 higher in the first data set than the second data set.

\subsection{Effective dose equivalent}

The specific activities of the natural radionuclides from drinking water are due to the presence of naturally occurring radionuclides of both the uranium and thorium decay series. To calculate the annual internal dose, we used the values of effective dose conversion factor by ingestion (CF) shown in Table 2 for each radionuclide of interest [16]:
Table 2. Effective dose conversion factor for ${ }^{210} \mathrm{Po},{ }^{210} \mathrm{~Pb}$ and ${ }^{226} \mathrm{Ra}$

\begin{tabular}{|c|c|c|c|c|}
\hline \multirow[b]{2}{*}{$\begin{array}{l}\text { Radionu- } \\
\text { clide }\end{array}$} & \multirow[b]{2}{*}{$\mathrm{T} 1 / 2$} & \multicolumn{3}{|c|}{$\begin{array}{c}\text { Effective dose conversion } \\
\left.\text { factor by ingestion, } \mathrm{CF}(\mathrm{Sv} \mathrm{Bq})^{-1}\right)\end{array}$} \\
\hline & & $\begin{array}{l}\text { lactation } \\
\text { age }^{*}\end{array}$ & $\begin{array}{c}\text { children } \\
\text { (1-17 } \\
\text { years) }\end{array}$ & $\begin{array}{c}\text { adults } \\
(>17 \\
\text { years })\end{array}$ \\
\hline${ }^{226} \mathrm{Ra}$ & $1600 \mathrm{y}$ & $4.7 \mathrm{E}-06$ & $1.5 \mathrm{E}-06$ & $\begin{array}{l}2.8 \mathrm{E}- \\
07\end{array}$ \\
\hline${ }^{210} \mathrm{~Pb}$ & $22.3 \mathrm{y}$ & $8.4 \mathrm{E}-06$ & $1.9 \mathrm{E}-06$ & $\begin{array}{l}6.9 \mathrm{E}- \\
07\end{array}$ \\
\hline${ }^{210} \mathrm{Po}$ & $138 \mathrm{~d}$ & 2.6E-O5 & $1.6 \mathrm{E}-06$ & $\begin{array}{l}1.2 \mathrm{E}- \\
06\end{array}$ \\
\hline
\end{tabular}

*lactation age-babies without breast feeding

In order to assess the health risk for population, the annual effective dose equivalent associated with radiation exposure through ingestion of the all water samples was estimated with the formula:

$$
D_{e f}=\Sigma\left(A_{Y} \times I R_{W} \times C F\right)
$$

where Def is the annual effective dose equivalent $\left(\mathrm{Sv}^{-1}\right), \mathrm{A}_{\mathrm{y}}$ - the activity concentration of radionuclide $\mathrm{Y}\left(\mathrm{Y}={ }^{210} \mathrm{Po},{ }^{210} \mathrm{~Pb},{ }^{226} \mathrm{Ra}\right)\left(\mathrm{Bq} \mathrm{L} \mathrm{L}^{-1}\right), \mathrm{IRw}$-water intake by one person during one year $\left(\mathrm{L} \mathrm{y}^{-1}\right), \mathrm{CF}$ - effective dose conversion factor $\left(\mathrm{Sv} \mathrm{Bq}{ }^{-1}\right)$, given in Table 2 for each age category of population. The annual consumption rate was estimated at the value of $730 \mathrm{~L}$ for adults, 350 $\mathrm{L}$ for children and $250 \mathrm{~L}$ for lactation age, according to WHO 2011 [1]. The results obtained by us for the annual effective dose equivalent due to ingestion of ${ }^{210} \mathrm{Po}{ }^{210} \mathrm{~Pb}$ and ${ }^{226} \mathrm{Ra}$ radionuclides from drinking water are presented in Table 3. 
Table 3. The annual effective dose equivalent due to ingestion of ${ }^{210} \mathrm{Po},{ }^{210} \mathrm{~Pb}$, and ${ }^{226} \mathrm{Ra}$ from drinking water

\begin{tabular}{|c|c|c|c|c|c|c|c|c|c|c|c|c|c|}
\hline \multirow{2}{*}{$\frac{0}{\mathscr{2}}$} & \multirow[t]{2}{*}{ Persons } & \multicolumn{3}{|c|}{$\begin{array}{l}\text { Efective dose due to } \\
\text { ingestion of }{ }^{210} \mathrm{Po} \\
\left(\mu \mathrm{Sv} \mathrm{y}^{-1}\right)\end{array}$} & \multicolumn{3}{|c|}{$\begin{array}{c}\text { Efective dose due to } \\
\text { ingestion of }{ }^{210} \mathrm{~Pb} \\
\left(\mu \mathrm{Sv} \mathrm{y}^{-1}\right)\end{array}$} & \multicolumn{3}{|c|}{$\begin{array}{c}\text { Efective dose due to } \\
\text { ingestion of } 226 \mathrm{Ra} \\
\left(\mu \mathrm{Sv} \mathrm{y}^{-1}\right)\end{array}$} & \multicolumn{3}{|c|}{$\begin{array}{l}\text { Total effective dose } \\
\qquad\left(\mu \mathrm{Sv} \mathrm{y}^{-1}\right)\end{array}$} \\
\hline & & $\begin{array}{c}\text { lactation } \\
\text { age }\end{array}$ & $\begin{array}{c}\text { childre } \\
\mathrm{n}\end{array}$ & adults & $\begin{array}{l}\text { lactatio } \\
\mathrm{n} \text { age }\end{array}$ & $\begin{array}{c}\text { childre } \\
n\end{array}$ & adults & $\begin{array}{l}\text { lactatio } \\
\text { n age }\end{array}$ & children & adults & $\begin{array}{l}\text { tio } \\
\text { se }\end{array}$ & $\mathrm{n}$ & dult \\
\hline DW1 & & \pm 2.79 & & & $\begin{array}{r}6.83 \\
\pm 1.57\end{array}$ & $\begin{array}{l}6 \\
0 \\
\end{array}$ & $\begin{array}{r}1.04 \\
\pm 0.38 \\
\end{array}$ & $\begin{array}{r}35.25 \\
\pm 10.58 \\
\end{array}$ & $\begin{array}{r}2 \\
\pm 0 \\
\end{array}$ & & & & 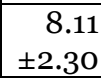 \\
\hline W2 & & \pm 2.72 & & & $\begin{array}{r}6.76 \\
\pm 1.55 \\
\end{array}$ & $\begin{array}{r}2.14 \\
\pm 0.49 \\
\end{array}$ & $\begin{array}{r}1.62 \\
\pm 0.37 \\
\end{array}$ & $\begin{array}{l}27.03 \\
\pm 8.11 \\
\end{array}$ & $\begin{array}{r}2.25 \\
\pm 0.68 \\
\end{array}$ & $\begin{array}{r}4.83 \\
\pm 1.45 \\
\end{array}$ & $\begin{array}{r}46.1 \\
\pm 12.3 \\
\end{array}$ & & $r_{1}$ \\
\hline$W_{3}$ & & & & & & & 2.66 & $\begin{array}{r}15.28 \\
\pm 4.58 \\
\end{array}$ & $\begin{array}{r}1.27 \\
\pm 0.38 \\
\end{array}$ & $\begin{array}{r}2.73 \\
\pm 0.82 \\
\end{array}$ & & & \\
\hline & & $\begin{array}{r}77.94 \\
\pm 17.15 \\
\end{array}$ & 6 & & & $\begin{array}{r}5.60 \\
\pm 1.12 \\
\end{array}$ & 4. & $\begin{array}{r}31.73 \\
\pm 9.52 \\
\end{array}$ & $\begin{array}{r}2.65 \\
\pm 0.79 \\
\end{array}$ & $\begin{array}{r}5.67 \\
\pm 1.70 \\
\end{array}$ & & & \\
\hline W5 & 25 & $\begin{array}{r}79.06 \\
\pm 17.39 \\
\end{array}$ & & & $\begin{array}{r}7.01 \\
\pm 1.61 \\
\end{array}$ & $\begin{array}{r}2.22 \\
\pm 0.51 \\
\end{array}$ & $\begin{array}{r}1.68 \\
\pm 0.39 \\
\end{array}$ & $\begin{array}{l}3.50 \\
7.05\end{array}$ & $\begin{array}{r}1.96 \\
\pm 0.59 \\
\end{array}$ & $\begin{array}{r}4.20 \\
\pm 1.26 \\
\end{array}$ & & & \\
\hline W6 & 669 & $\begin{array}{r}13.07 \\
\pm 2.87 \\
\end{array}$ & $\begin{array}{r}1.13 \\
\pm 0.25 \\
\end{array}$ & 0.04 & $\begin{array}{l}24.65 \\
\pm 5.67 \\
\end{array}$ & $\begin{array}{r}7.80 \\
\pm 1.79 \\
\end{array}$ & $\begin{array}{r}5.91 \\
\pm 1.36 \\
\end{array}$ & $\begin{array}{r}21.15 \\
\pm 6.35 \\
\end{array}$ & $\begin{array}{r}1.76 \\
\pm 0.53 \\
\end{array}$ & $\begin{array}{r}3.78 \\
\pm 1.13 \\
\end{array}$ & 58.86 & & $\begin{array}{r}9.8 \\
\pm 2.5 \\
\end{array}$ \\
\hline$W_{7}$ & 5 & $\begin{array}{r}81.12 \\
\pm 17.85 \\
\end{array}$ & $\begin{array}{r}6.99 \\
\pm 1.54 \\
\end{array}$ & \pm 0. & $\begin{array}{r}7.88 \\
\pm 1.81 \\
\end{array}$ & $\begin{array}{r}2.49 \\
\pm 0.57 \\
\end{array}$ & $\begin{array}{r}1.89 \\
\pm 0.43 \\
\end{array}$ & $\begin{array}{r}31.73 \\
\pm 9.52 \\
\end{array}$ & $\begin{array}{r}2.65 \\
\pm 0.79 \\
\end{array}$ & $\begin{array}{r}5.67 \\
\pm 1.70 \\
\end{array}$ & $1<9.1$ & & $\begin{array}{r}8.6 \\
\pm 2.3 \\
\end{array}$ \\
\hline & 750 & & & & & $\begin{array}{r}4.98 \\
\pm 1.00 \\
\end{array}$ & $\begin{array}{r}3 \\
\pm 0 \\
\end{array}$ & & $\begin{array}{r}1.96 \\
\pm 0.59 \\
\end{array}$ & $\begin{array}{r}4.20 \\
\pm 1.26 \\
\end{array}$ & 54.66 & & \pm 2.0 \\
\hline & & & & & & $\begin{array}{r}3.51 \\
\pm 0.74 \\
\end{array}$ & 2. & & $\begin{array}{r}2.65 \\
\pm 0.79 \\
\end{array}$ & $\begin{array}{r}5.67 \\
\pm 1.70 \\
\end{array}$ & & & \pm 2. \\
\hline 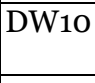 & 771 & $\begin{array}{l}94 \\
85 \\
\end{array}$ & $\begin{array}{r}1.11 \\
\pm 0.25 \\
\end{array}$ & & & $\begin{array}{r}2.55 \\
\pm 0.53 \\
\end{array}$ & 1.9 & & $\begin{array}{r}2.25 \\
\pm 0.68 \\
\end{array}$ & $\begin{array}{r}4.83 \\
\pm 1.45 \\
\end{array}$ & & & \\
\hline W11 & 5 & & $\begin{array}{r}4.37 \\
\pm 0.96 \\
\end{array}$ & & & $\begin{array}{r}5.09 \\
\pm 1.02 \\
\end{array}$ & $\begin{array}{r}3.86 \\
\pm 0.77 \\
\end{array}$ & $\begin{array}{r}9.40 \\
\pm 2.82 \\
\end{array}$ & $\begin{array}{r}0.78 \\
\pm 0.24 \\
\end{array}$ & $\begin{array}{r}1.68 \\
\pm 0.50 \\
\end{array}$ & $\begin{array}{r}76.21 \\
\pm 17.20 \\
\end{array}$ & & 6 ? \\
\hline V1 & 18432 & \begin{tabular}{r|}
18.28 \\
4.02 \\
\end{tabular} & $\begin{array}{r}1.58 \\
\pm 0.35 \\
\end{array}$ & 0.25 & $\begin{array}{r}6.93 \\
\pm 1.46 \\
\end{array}$ & $\begin{array}{r}2.19 \\
\pm 0.46 \\
\end{array}$ & $\begin{array}{r}1.66 \\
\pm 0.35 \\
\end{array}$ & $\begin{array}{r}9.40 \\
\pm 2.82 \\
\end{array}$ & $\begin{array}{r}0.78 \\
\pm 0.24 \\
\end{array}$ & $\begin{array}{r}1.68 \\
\pm 0.50 \\
\end{array}$ & $\begin{array}{r}34.61 \\
\pm 8.30 \\
\end{array}$ & & $\begin{array}{r}3.5 \\
\pm 0.4 \\
\end{array}$ \\
\hline 2013 & 98646 & $\begin{array}{l}2.68 \\
2.79 \\
\end{array}$ & $\begin{array}{r}1.09 \\
\pm 0.24 \\
\end{array}$ & $\begin{array}{r}0.17 \\
\pm 0.04 \\
\end{array}$ & $\begin{array}{r}13.22 \\
\pm 3.04 \\
\end{array}$ & $\begin{array}{r}4.19 \\
\pm 0.96 \\
\end{array}$ & $\begin{array}{r}3.17 \\
\pm 0.73 \\
\end{array}$ & $\begin{array}{r}9.40 \\
\pm 2.82 \\
\end{array}$ & $\begin{array}{r}0.78 \\
\pm 0.24 \\
\end{array}$ & $\begin{array}{r}1.68 \\
\pm 0.50 \\
\end{array}$ & $\begin{array}{r}35.2 \\
\pm 8.6 \\
\end{array}$ & -5 & $\begin{array}{r}5.0 \\
\pm 1.2 \\
\end{array}$ \\
\hline $8 v 14$ & 0500 & 2.35 & $\begin{array}{r}1.06 \\
\pm 0.23 \\
\end{array}$ & 0 & $\begin{array}{r}7.14 \\
\pm 1.50 \\
\end{array}$ & $\begin{array}{r}2.26 \\
\pm 0.47 \\
\end{array}$ & $\begin{array}{r}1.71 \\
\pm 0.36 \\
\end{array}$ & $\begin{array}{r}17.63 \\
\pm 5.29\end{array}$ & $\begin{array}{r}1.47 \\
\pm 0.44 \\
\end{array}$ & $\begin{array}{r}3.15 \\
\pm 0.95 \\
\end{array}$ & $\begin{array}{r}37.12 \\
\pm 9.50 \\
\end{array}$ & 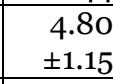 & $\begin{array}{r}5.0 \\
\pm 1.3 \\
\end{array}$ \\
\hline 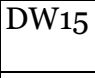 & 8735 & $\begin{array}{r}12.87 \\
\pm 2.83 \\
\end{array}$ & $\begin{array}{r}1.11 \\
\pm 0.24 \\
\end{array}$ & 0 & $\begin{array}{r}9.20 \\
\pm 2.11 \\
\end{array}$ & $\begin{array}{r}2.91 \\
\pm 0.67 \\
\end{array}$ & $\begin{array}{r}2.21 \\
\pm 0.5 \\
\end{array}$ & $\begin{array}{r}28.20 \\
\pm 8.46 \\
\end{array}$ & $\begin{array}{r}2.35 \\
\pm 0.71 \\
\end{array}$ & $\begin{array}{r}5.04 \\
\pm 1.51 \\
\end{array}$ & $\begin{array}{r}50.27 \\
\pm 13.41 \\
\end{array}$ & $\begin{array}{r}6.37 \\
+1.62 \\
\end{array}$ & $\begin{array}{r}7.4 \\
\pm 2.0 \\
\end{array}$ \\
\hline 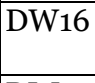 & 12007 & $\begin{array}{r}12.87 \\
\pm 2.83 \\
\end{array}$ & $\begin{array}{r}1.11 \\
\pm 0.24 \\
\end{array}$ & $\begin{array}{r}0.17 \\
\pm 0.04 \\
\end{array}$ & $\begin{array}{r}6.74 \\
\pm 0.10 \\
\end{array}$ & $\begin{array}{r}2.13 \\
\pm 0.03 \\
\end{array}$ & $\begin{array}{r}1.62 \\
\pm 0.02 \\
\end{array}$ & $\begin{array}{r}31.73 \\
\pm 9.52 \\
\end{array}$ & $\begin{array}{r}2.65 \\
\pm 0.79 \\
\end{array}$ & $\begin{array}{r}5.67 \\
\pm 1.70 \\
\end{array}$ & $\begin{array}{r}51.34 \\
\pm 12.45 \\
\end{array}$ & $\begin{array}{r}5.89 \\
\pm 1.07 \\
\end{array}$ & $\begin{array}{r}7.4 \\
\pm 1.7 \\
\end{array}$ \\
\hline & , & $\begin{array}{l}28.93 \\
\pm 6.36 \\
\end{array}$ & $\begin{array}{r}2.49 \\
\pm 0.55 \\
\end{array}$ & $\begin{array}{r}0.3 \\
\pm 0.0 \\
\end{array}$ & $\begin{array}{l}25.89 \\
\pm 7.67 \\
\end{array}$ & $\begin{array}{r}8.20 \\
\pm 2.43 \\
\end{array}$ & $\begin{array}{r}6.21 \\
\pm 1.84 \\
\end{array}$ & $\begin{array}{r}16.45 \\
\pm 4.94 \\
\end{array}$ & $\begin{array}{r}1.37 \\
\pm 0.41 \\
\end{array}$ & $\begin{array}{r}2.94 \\
\pm 0.88 \\
\end{array}$ & $\begin{array}{r}78.77 \\
\pm 18.96 \\
\end{array}$ & $\begin{array}{r}14.4 \\
\pm 3.3 \\
\end{array}$ & $\begin{array}{r}11.3 \\
\pm 2.8 \\
\end{array}$ \\
\hline
\end{tabular}

The annual effective dose equivalent associated with radiation exposure through water intake allows assessing the health risk for adult, children and baby members of the population. The results from this study (Table 3) indicated that the annual effective dose equivalents are lower than the WHO recommended level of $100 \mu \mathrm{Sv} \mathrm{y}^{-1}$ for children and adults, while the highest values have been found for lactation age (for the sample DW4, Dw5 and DW7 from Galati). As expected, the highest values of the effective dose equivalent correspond to the samples having the largest activity concentration of ${ }^{210}$ Po. The main reason is its higher conversion factor. The annual effective dose equivalent has an average value of $63.79 \pm 15.75$ $\mu \mathrm{Sv} \mathrm{y}^{-1}$ for babies, $8.26 \pm 1.94 \mu \mathrm{Sv} \mathrm{y}^{-1}$ for children and $7.44 \pm 1.93 \mu \mathrm{Sv}^{-1}$ for adults.

\section{Conclusions}

This is the first detailed study of radionuclide concentration in drinking water from Galati and Vrancea areas, Romania. Also, it is the first study regarding the assessment of the annual effective dose equivalent due to the drinking water consumption in this area. This was achieved as a result of the new requirements according to the Law 301/2015. Provisions of the European Directive 51/2013 were transported into Romanian national legislation through the Law 301/2015 [17] by establishing health protection requirements regarding the radioactive substances in drinking water.

The gross alpha, gross beta, ${ }^{210} \mathrm{Po},{ }^{210} \mathrm{~Pb}$ and ${ }^{226} \mathrm{Ra}$ activity concentrations of drinking water in 2015 in the most important waterworks from Galati and Vrancea areas, Romania, were measured. The activity concentration data obtained in this study are lower than the guidance level according to World Health Organization and nationals rules.

The values for the annual effective dose equivalent due to the consumption of drinking water have been found below $100 \mu \mathrm{Sv} \mathrm{y}^{-1}$, except for babies (without breast-feeding). These values correspond to the samples DW4, DW5, DW7 (notwithstanding that the activity concentration of the investigated radionuclides had values below maximum concentrations allowed). 
This study highlights the fact that although the values of activity concentrations for the investigated radionuclides are lower than the maximum allowed concentration, the recommended annual effective dose (100 $\mu \mathrm{Sv} \mathrm{y}^{-1}$ ) can be exceeded. It is necessary to monitor activity concentrations of radionuclides in drinking water (from Romania and generally), especially for the radionuclides with the highest effective dose conversion factor in order to assess the equivalent annual effective dose.

Acknowledgement: VP would like to express her deepest gratitude to the Ionizing Radiation Hygiene Laboratory Galatifor the technical support.

\section{REFERENCES}

1. United Nations Scientific Committee on the Effect of Atomic Radiation (UNSCEAR) Sources and effects of ionizing radiation United Nations (2000).

2. World Health Organization (WHO). Guidelines for drinking water quality, WHO (2011).

3. Council Directive 2013/51 Euratom laying down requirements for the protection of the health of the general public with regard to radioactive substances in water intended for human consumption.

4. G.M. Stewart, S. W. Fowler and S.W. Fisher. "The bioaccumulation of $\mathrm{U}$ - and Th-series radionuclides in marine organisms", Radioactivity in the Environment, vol. 13, pp. 269-305, 2008.

5. J. Molinari and W.J. Snodgrass, "The chemistry and radiochemistry of radium and the other uranium and thorium natural decay series," The Environmental behavior of radium, IAEA 1, pp.1-56, 1990.
6. Guidelines for drinking-water quality-Third edition incorporating the first and second addenda, Vol. 1, Recommendation World Health Organization, 2008.

7. The Council of Galati County Retrieved from: http://www.cjgalati.ro/index.php/judeul-galai

8. The Council of Vrancea County Retrieved from: http://www.cjvrancea.ro/files/file/Strategia\%20de\%20 dezvoltare\%20a\%20jud/hot177anexa.pdf

9. Water quality - Measurement of gross alpha activity in non-saline water - Thick source method, ISO 9697:2007

10. Water quality - Measurement of gross beta activity in non-saline water - Thick source method, ISO 9696:2008

11. Operating manual technical documentation low background total alpha and beta global - alpha measuring system type Protean-PIC. MPC-2000-DP.

12. Water. The analysis of Po-21O concentration in water. STAS $12444,86$.

13. The methodological book Radiation Hygiene, Ministry of Health, 1981

14. Operating manual technical documentation of module SARAD RTM-1688-2.

15. Drinking water. STAS 1342, 1991

16. Norme Fundamentale de Securitate Radiologica Retrieved from: http://www.cncan.ro/assets/NSR/nsro1.pdf

17. Law 301/2015 by establishing health protection requirements regarding the radioactive substances in drinking water, Monitorul Official, 2015. 